\title{
a-Glucosidase Inhibitory Effects for Solvent Fractions from Methanol Extracts of Sargassum fulvellum and Its Antioxidant and Alcohol-Metabolizing Activities
}

\author{
Su Hee Kang ${ }^{\dagger}$, Eun Kyung $\mathrm{Cho}^{\dagger}$ and Young Ju Choi*
}

Department of Food and Nutrition, College of Medical Life Sciences, Silla University, Busan 617-736, Korea

Received September 20, 2012 /Revised October 16, 2012 /Accepted October 24, 2012

\begin{abstract}
We investigated the physiological activity and solvent-partitioned fractions of methanol extracts from the green seaweed Sargassum fulvellum The methanol extract from $S$. fulvellum was sequentially fractionated with n-hexane (SFMH), methanol (SFMM), buthanol (SFMB), and water (SFMA). We investigated the antioxidant activities of solvent fractions from $S$. fulvellum by using 1,1-diphenyl-2-picrylhydrazyl (DPPH) radical scavenging capacity and an SOD activity assay. DPPH radical scavenging capacity of SFMM was $79.5 \%$ at $10 \mathrm{mg} / \mathrm{ml}$. SOD activity of SFMM was $79.9 \%$ at $10 \mathrm{mg} / \mathrm{ml}$. Nitrite scavenging activities of solvent fractions from $S$. fulvellum were investigated under different $\mathrm{pH}$ conditions and showed the most remarkable effect at $\mathrm{pH}$ 1.2. In particular, the activity of SFMB was higher than the other fractions. ADH activity and ALDH activity of SFMM were $177.0 \%$ and $167.4 \%$ at $10 \mathrm{mg} / \mathrm{ml}$, respectively. a-Glucosidase inhibitory activity of SFMH increased in a dose-dependent manner and was about $94.1 \%$ at $2 \mathrm{mg} / \mathrm{ml}$. Elastase inhibitory activity was $93.2 \%$ at $2 \mathrm{mg} / \mathrm{ml}$. These results revealed that $S$. fulvellum extracts have strong antioxidant and alcohol dehydrogenase activities and a -glucosidase inhibitory activity, suggesting that $S$. fulvellum extracts have potential as a source of natural products for health and beauty.
\end{abstract}

Key words : Sargassum fulvellum, antioxidative activity, alcohol dehydrogenase, a-glucosidase, elastase

\section{서 론}

지구 생물 중 약 $80 \%$ 를 차지하는 해양생물[21]은 육상생물 에 비해 고염, 고압의 특수한 환경에서 생육하면서 다양한 미 네랄 성분을 함유하고 있어 오래전부터 한국, 일본 등 극동 아시아 지역에서 우수한 먹을거리로서 이용되어 왔다[17]. 그 중 식용으로 쓰이는 해조류는 일반적으로 열량 및 영양성분은 낮은 편이지만 다양한 생리활성 물질들을 함유하고 있는 것으 로 보고되고 있다. 해조류는 건강에 필수적인 다양한 무기염 류들을 다량 함유하고 있으며, 특히 비소화성 복합다당류 (agar, alginic acid, fucoidan, laminaran, starch)들은 다양한 생리활성 기능을 가지고 있는 것으로 알려져 있다. 또한 항균, 함염증, 항암, 항당뇨 및 항산화 등 많은 생리활성을 가지고 있는 것으로 밝혀지면서 해조류에 대한 생리활성 연구가 활발 히 진행되고 있다 $[10,20,23,26,38]$. 해조류에는 알긴산과 칼슘 이온, 요오드 성분이 많기 때문에 대장의 연동운동 촉진과 골 다공증 예방 및 갑상선 부종을 억제 시키는 역할을 하는 것으 로 보고되어 있다[1].

모자반(Sargassum fulvellum)은 다년생 갈조류로 한국, 일본 등 동남아시아 일대에 분포되어 있으며 우리나라에서는 전 해안에서 폭 넓게 자생하고 있는 해조류이다. 우리나라에서

\footnotetext{
${ }^{\dagger}$ These authors have contributed equally to this work.

*Corresponding author

Tel : +82-51-999-5459, Fax : +82-51-999-6959

E-mail : yjchoi@silla.ac.kr
}

생 육하는 모자반은 괭생이모자반, 알쏭이모자반, 꽈배기모자 반, 큰잎모자반, 짝잎모자반, 쌍발이모자반 등 약 20여 종이 분포하고 있으며, 특히 식용으로 이용되는 대표적인 모자반은 흔히 '참몰' 또는 '참모자반'으로 불려지고 있다.

모자반 일반성분은 조단백질 $15.8 \%$, 조지질 $5.0 \%$, 조회분 $27.5 \%$ 및 총 탄수화물이 $51.7 \%$ 로 가장 함량이 높은 것으로 보고되고 있다[19,23]. 모자반의 주된 복합다당류는 fucoidan 이었으며 그 외에도 갈조류의 저장 다당인 laminaran, 알긴산 등이 함께 있는 것으로 알려져 있다. Heo 등[12]은 특히 모자 반 fucoidan의 $50 \%$ 이상이 우론산과 단백질로 혼입되어 있다 고 보고하였다.

모자반에 대한 생리활성연구는 유기용매 추출을 통한 항균 실험과 열 및 $\mathrm{pH}$ 안정성에 대한 연구[32] 및 유기용매 분획물 의 항발암효과 등에 관한 보고가 있다[2]. Koo 등[19]은 fucoi$\mathrm{dan}$ 의 항혈액응고 특성에 대한 연구를 수행하였으며, 갈조류 의 효소적 가수분해물의 항산화 효과에 대한 연구도 보고 되 고 있다[11,12]. 최근 Cho 등[5]은 꽈배기 모자반에서 항산화 특성을 보고하였으며, Hwang 등[13]은 짝잎모자반에서 추출 된 복합다당류가 면역기능에 효과가 있는 것으로 보고하였다. Kim 등[18]은 왜모자반에서 분리한 plastoquinone 화합물들 이 항산화 및 항당뇨 효능이 높은 것으로 보고하였다.

모자반에 대한 생리활성 연구는 주로 유기용매의 추출물을 이용한 한 가지 특성에 대한 실험들이 주를 이루고 있으며 아직 참모자반의 분획물에 대한 생리활성에 대한 연구는 거의 없는 실정이다. 따라서 본 연구에서는 모자반의 생리활성 연 
구를 위하여 모자반 메탄올 추출로부터 순차적 분획물을 얻고 이들의 항산화능, 숙취해소능, 혈당 강하효능, 미용효과 등에 연구함으로써 모자반을 이용한 기능성 소재개발의 기초자료 로 제시하고자 한다.

\section{재료 및 방법}

\section{실험 재료}

본 실험에 사용한 모자반(S. fulvellum)은 제주산 건 모자반 을 구입하여 세척, 건조 후 분쇄기로 분말을 제조한 후 $-20^{\circ} \mathrm{C}$ 에 서 보관하면서 모자반의 유기용매 추출 및 분획물 제조를 위 한 재료로 사용하였다.

\section{시료 추출 및 분획 제조}

실험에 사용된 모자반(S. fulvellum)은 건조 후 분쇄하여 시 료의 10 배량에 해당하는 $80 \%$ methanol을 가하여 24 시간동안 교반하며 3회 반복추출 하였다. 즉 $80 \%$ methanol 추출물을 물에 용해시켜 dichloromethane $\left(\mathrm{CH}_{2} \mathrm{Cl}_{2}\right)$ 분획과 aqueous 층 으로 나누고 dichloromethane층은 다시 $\mathrm{n}$-hexane 분획층과 methanol 분획층로 분리하였으며, aqueous 층은 다시 부탄올 분획층과 aqueous 분획층으로 분획하였다. 이와 같은 방법으 로 모자반 추출물을 극성층인 methanol층(SFMM), buthanol 층(SFMB), aqueous층(SFMA)과 비극성층인 hexane층 $(\mathrm{SFMH})$ 으로 나누어 비극성에서 극성쪽으로 계통 분획하고 각 분획층을 감압 농축 후 동결 건조하여 시료로 사용하였다.

\section{$\mathrm{DPPH}$ radical 소거능 측정}

모자반 분획물의 DPPH radical 소거능은 Blois의 방법[3]을 수정한 version에 따라 측정하였다. DPPH (2,2-Diphenyl-1picrylhydrazyl) 용액은 $100 \mathrm{ml}$ 에탄올에 $\mathrm{DPPH} 1.5 \times 10^{-4} \mathrm{M}$ 을 녹인 후 증류수 $100 \mathrm{ml}$ 를 혼합하여 Whatman filter paper No. 2로 여과하여 조제하였다. 96 well plate에 시료와 DPPH용액 을 $1: 4$ 비율로 혼합하여 $37^{\circ} \mathrm{C}$ 에서 30 분간 반응시킨 후, ELISA reader를 이용하여 $520 \mathrm{~nm}$ (Molecular Device, VersaMax Microplate Reader, Calfornia, USA)에서 흡광도를 측정하였 다. 전자공여능(Electron donating ability, $\mathrm{EDA})$ 은 $\mathrm{EDA}(\%)=$ (대조구흡광도-시료첨가구흡광도)/대조구흡광도× 100 으로 계 산하였다. 시료를 첨가하지 않은 대조그룹과 흡광도차를 비교 하여 free radical의 제거활성을 백분율로 나타내었다.

\section{$\mathrm{SOD}$ 활성 측정}

SOD (superoxide dismutase) 활성은 SOD assay kit (Dojindo Molecular Technologies, Rockville, USA)를 사용하 여 manufacturer's instruction에 기술된 방법에 따라서 수행 하였다. 시료를 농도별로 희석하여 96 well plate에 $20 \mu \mathrm{l}$ 씩 분주한 후, WST working solution을 $200 \mu \mathrm{l}$ 을 넣고 혼합한
다음 enzyme working solution을 $20 \mu \mathrm{l}$ 을 첨가하여 $37^{\circ} \mathrm{C}$ 에서 20 분간 incubation 한 후 $450 \mathrm{~nm}$ 에서 ELISA reader를 이용하 여 흡광도를 측정하였다. 대조구 실험은 효소 대신 $20 \mu \mathrm{dilu}-$ tion buffer를 넣었으며, SOD 활성은 시료 첨가구와 무첨가구 사이의 흡광도 차이를 백분율 $(\%)$ 로 나타내었다.

SOD activity $(\%)=(1-$ 시료 첨가구의 흡광도/시료 무첨가구 의 흡광도 $) \times 100$

\section{아질산염 소거능 측정}

아질산염 소거능은 Gray와 Dugan의 방법[9]을 변형하여 측정하였다. 아질산염 용액에 시료 용액 $1 \mathrm{ml}$ 을 가하고 여기에 $0.1 \mathrm{~N} \mathrm{HCl}(\mathrm{pH} 1.2)$ 및 $0.2 \mathrm{M}$ 구연산 완충용액( $\mathrm{pH}$ 3.0과 6.0)을 사용하여 반응 용액의 $\mathrm{pH}$ 를 각각 $1.2,3.0$ 및 6.0으로 조정하여 반응용액을 준비 하였다. 이를 $37^{\circ} \mathrm{C}$ 에서 1 시간동안 반응시킨 다음 반응액을 각각 $1 \mathrm{ml}$ 씩 취하고 Griess 시약을 가하여 혼합 시켜 15 분간 실온에 방치시킨 후, $520 \mathrm{~nm}$ 에서 ELISA reader를 이용하여 흡광도를 측정하여 잔존하는 아질산염을 구하였다. 대조구 실험은 Griess 시약 대신 증류수를 $0.4 \mathrm{ml}$ 가하여 상기 와 동일하게 행하였다. 아질산염 소거능은 다음과 같은 계산 식으로 계산하였다.

아질산염 소거율 $(\%)=[1-($ 실험첨가구의 흡광도-실험무첨가 구의 흡광도)/대조구의 흡광도]×100

\section{$\mathrm{ADH}$ (alcohol dehydrogenase) 활성 측정}

$\mathrm{ADH}$ 활성은 Choi 등[7]의 방법을 변형하여 측정하였다. 즉, 시험관에 $\mathrm{NAD} 300 \mu \mathrm{l}$, 증류수 $1.4 \mathrm{ml}, 1 \mathrm{M}$ Tris- $\mathrm{HCl}(\mathrm{pH}$ 8.8) buffer $750 \mu \mathrm{l}, 0.2 \mathrm{M}$ 에탄올 $300 \mu \mathrm{l}$, 시료 $100 \mu \mathrm{l}, \mathrm{ADH}$ 효소액 $150 \mu 1$ 를 넣고 $25^{\circ} \mathrm{C}$ 에서 10 분간 반응시킨 후 생성된 $\mathrm{NADH}$ 의 양을 $340 \mathrm{~nm}$ 에서 spectrophotometer (Amersham Pharmacia Biotech UK Ltd.)를 이용하여 측정하였다. 이때 대 조구는 시료대신 증류수를 넣었으며 positive control로 사용 한 hepos는 약국에서 구입한 것으로, 처방전에 따라 $1 / 2$ 로 희석하여 사용하였다. $\mathrm{ADH}$ 의 활성은 다음과 같은 식으로 계 산 되었다.

$\mathrm{ADH}$ activity $(\%)=(\mathrm{B} / \mathrm{A}) \times 100$

$\mathrm{A}$ : 대조구의 최대 흡광도

$\mathrm{B}$ : 실험구의 최대 흡광도

\section{$\mathrm{ALDH}$ (acetaldehyde dehydrogenase) 활성 측정}

$\mathrm{ALDH}$ 의 활성도는 Tottmar 등의 방법[31]을 변형하여 $\mathrm{NADH}$ 생성에 따른 흡광도의 변화를 spectrophotometer (Amersham Pharmacia Biotech UK Ltd.)를 이용하여 $340 \mathrm{~nm}$ 에서 측정하였다. 즉, $\mathrm{ALDH}$ 의 활성도 측정을 위해 증류수 $2.1 \mathrm{ml}, 1.0 \mathrm{M}$ Tris- $\mathrm{HCl}$ buffer (pH 8.0) $0.3 \mathrm{ml}, 20 \mathrm{mM} \mathrm{NAD}^{+}$ $0.1 \mathrm{ml}, 0.1 \mathrm{M}$ acetaldehyde $0.1 \mathrm{ml}, 3.0 \mathrm{M} \mathrm{KCl} 0.1 \mathrm{ml}, 0.33$ $\mathrm{M}$ 2-mercaptoethanol $0.1 \mathrm{ml}$, 시료 $0.1 \mathrm{ml}$ 를 혼합한 다음 $25^{\circ} \mathrm{C}$ 
에서 10 분간 반응시키고 $\mathrm{ALDH}$ 효소액 $150 \mu 1$ 를 가하여 흡광 도의 변화를 측정하였다. 이때 대조구는 시료대신 증류수를 넣은 것으로 하였다. Positive control은 $\mathrm{ADH}$ 활성 측정에서 사용한 것과 동일한 것으로 하였으며, $\mathrm{ALDH}$ 의 활성은 $\mathrm{ADH}$ 활성 계산식에 따라 측정되었다.

\section{a-Glucosidase 저해 활성 측정}

a-Glucosidase 저해활성 측정은 Tibbot의 방법[30]에 따라 측정하였다. $50 \mathrm{mM}$ sodium succinate buffer ( $\mathrm{pH}$ 4.2)에 pnitrophenyl-a-D-glucopyranoside (PNPG)를 용해시켜 $1 \mathrm{mg}$ / $\mathrm{ml}$ 의 농도로 기질을 만들고, 기질용액 $0.2 \mathrm{ml}$ 과 효소액 0.075 unit $/ \mathrm{ml}$ 를 혼합하여 대조구는 증류수 $0.1 \mathrm{ml}$, 반응구에는 시 료 $0.1 \mathrm{ml}$ 를 넣어 $37^{\circ} \mathrm{C}$ 에서 30 분간 반응시킨 후 $1 \mathrm{~N}-\mathrm{NaOH}$ $0.1 \mathrm{ml}$ 를 첨가하여 발색시켰다. Positive control로는 acarbose 를 사용하여 실험하였으며 a-glucosidase 효소 활성측정은 생 성된 p-nitrophenol (PNP)양을 $450 \mathrm{~nm}$ 에서 ELISA reader를 이용하여 흡광도를 측정하여 다음의 식으로 저해율을 산출하 였다.

저해율 $(\%)=[1$-(반응구의 $\rho$-nitrophenol생성량/대조구의 $\rho$ -nitrophenol 생성량)] $\times 100$

\section{Elastase 저해활성 측정}

피부노화, 특히 주름생성에 있어 주된 역할을 하는 matrix metallo proteinases (MMPs)인 elastase의 저해활성은 James 의 방법[14]에 따라 측정하였다. $50 \mathrm{mM}$ Tris- $\mathrm{HCl}$ buffer $(\mathrm{pH}$ 8.2)에 기질인 $N$-succinyl-(L-Ala)3-pnitroniline을 $0.5 \mathrm{mM}$ 농 도로 용해시킨 후 시료 및 elastase 효소액을 각각 50 lㅣ씩 첨가 하였다. 이 혼합액을 $25^{\circ} \mathrm{C}$ 에서 10 분간 반응시킨 후 기질로부 터 생성되는 pnitroanilide의 생성량을 $415 \mathrm{~nm}$ 에서 ELISA reader를 이용하여 흡광도를 측정하였다. Elastase 저해활성은 시료용액 첨가구와 무첨가구의 흡광도 감소율로 나타내었다. 저해율 $(\%)=[1-$ 시료첨가구의 흡광도/무첨가구의 흡광도] $\times 100$

\section{결과 및 고찰}

\section{DPPH radical 소거능}

모자반 분획물의 DPPH radical 소거능 측정결과는 Fig. 1에 나타내었다. DPPH radical 소거능은 모든 용매 분획층에서 농도 의존적으로 활성이 증가하는 것으로 나타났다. 특히 메 탄올 분획층은 $10 \mathrm{mg} / \mathrm{ml}$ 의 농도에서 $79.5 \%$ 의 가장 높은 항산 화활성을 나타났으며, 핵산 분획층 $(26.0 \%)$, 물 분획층 $(4.9 \%)$, 부탄올 분획층 $4.5 \%)$ 의 순으로 항산화 활성이 나타났다. 이러 한 결과는 positive control로 사용한 ascorbic acid의 농도 0.1 $\mathrm{mg} / \mathrm{ml}$ 와 비슷한 항산화 활성을 나타내었다.

Cho 등[5]이 보고한 꽈배기 모자반 추출물의 소거능

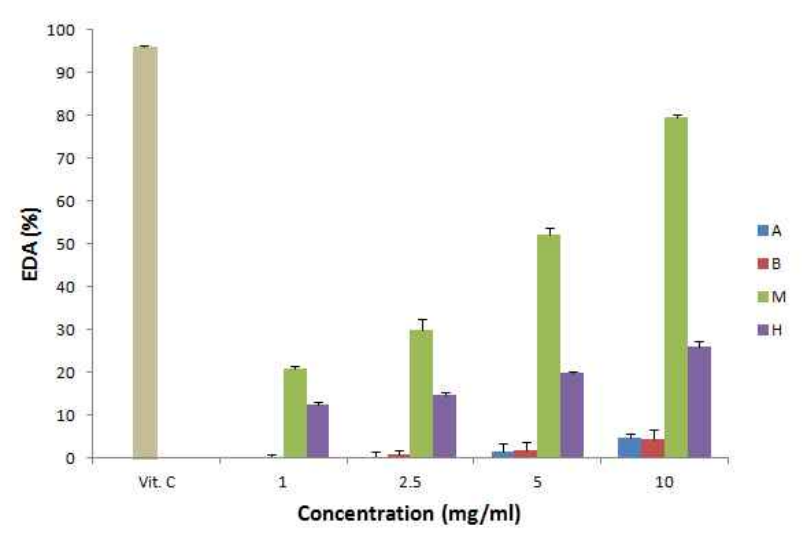

Fig. 1. DPPH free radical scavenging activities of solvent fractions of Sargassum fulvellum. Results are mean \pm S.D. of triplicate data. Vit. C $(0.1 \mathrm{mg} / \mathrm{ml}$, ascorbic acid $)$ is used as positive control. EDA (\%); Electron Donating Activity. A: Aqueous fr., B: Butanol fr., M: Methanol fr., $\mathrm{H}$ : Hexane fr.

은 chloroform>ethanol>물 층으로 나타났으며 특히 chloroform 추출물 $5 \mathrm{mg} / \mathrm{ml}$ 의 농도에서 $100 \% \mathrm{DPPH}$ radical 소거 효과를 나타내었다. Matsukawa 등[27]은 모자반과 3종의 물 추출물이 $50 \%$ 이상의 radical 소거능을 나타내어 높은 항산화 활성을 함유하는 것으로 보고하였다. 그런데 Lee 등[22]은 추 출용매에 따른 해조류의 항산화 활성을 측정하였는데 물 추출 물에서는 거의 활성이 보이지 않는 반면 에탄올 층에서 높은 항산화 활성을 보고하였다. Kim 등[15]은 경단구슬모자반 (Sargassum muticum) 에탄올 추출물 및 순차적 분획물에서 디 클로로메탄과 에틸아세트에트 분획물의 DPPH radical 소거 활성이 다른 분획층에 비해 비교적 높은 항산화 활성을 나타 내는 것으로 보고하였다.

$\mathrm{DPPH}$ 는 주로 phenolic compound 및 aromatic amine compound의 radical 소거능 측정을 위하여 사용되며, 알코올 성 $\mathrm{DPPH}$ 용액은 실온에서 1 시간 동안 안정하여 electron donation 활성을 측정하는데 많이 사용된다. 참모자반(S. fulvelI lum) 추출물의 활성은 ascorbic acid와 비교하였는데 이러한 결과는 SOD 활성과 유사하게 나타났다. Lee 등[27]은 약용식 물 추츨물의 DPPH radical 소거능이 phenolic 함량과 밀접한 관계가 있으며 추출물에 함유된 polyphenol 함량에 의존하는 것으로 보고하였다. 이러한 결과는 해조류에 존재하는 polyphenol 함량이 높은 꽈배기 모자반 추출물이 높은 소거능을 가진다는 연구 결과와 일치한다[5].

\section{SOD (superoxide dismutase) 활성}

인체 내 대사활동이 가장 왕성하게 일어나는 미토콘드리아 에서 활성산소종(reactive oxygen species; ROS)이 발생한다. 이러한 free radical은 세포막에 작용하여 과산화 지질을 생성 하여 세포막에 손상을 주거나, DNA 및 단백질에 손상을 초래 
하여 암 및 노화에 영향을 주는 것으로 알려져 있다.

모자반 분획물의 SOD 활성은 4 개의 분획층 모두 농도 의존 적으로 증가하는 경향을 보였으며 그중 메탄올 분획층이 가장 높은 SOD 활성을 나타내었다(Fig. 2). 메탄올 분획층은 농도가 증가함에 따라 SOD 활성이 증가되었으며, $10 \mathrm{mg} / \mathrm{ml}$ 의 농도 에서 $79.9 \%$ 로 높은 활성을 나타냈다. 다음은 부탄올 분획층 $(44.0 \%)$, 수층 $(26.8 \%)$, 핵산 분획층 $(16.0 \%)$ 순으로 나타났다. Kim 등[16]은 경단구슬모자반으로부터 분리한 sulfated polysaccharide의 SOD 활성은 $10 \mathrm{mg} / \mathrm{ml}$ 농도에서 $30 \%$ 의 활성을 나타내었다. Choi 등[8]은 지충이 chloroform 층의 SOD 유사 활성은 $1 \mathrm{mg} / \mathrm{ml}$ 에서 $61.4 \%$ 의 항산화효과를 나타내었다. 대 부분의 해조류 추출물연구에서 SOD 활성은 주로 용매추출물 에 대한 결과로서 SOD 유사활성으로 측정하였는데 이러한 실험의 문제점은 수율이 낮고, 추출시 고온을 이용하기 때문 에 열에 불안정한 항산화 물질이 파괴되었을 가능성이 높은 것으로 알려져 있다.

\section{아질산염 소거능}

참모자반의 용매 분획별 아질산염 소거능은 시료농도 1 $\mathrm{mg} / \mathrm{ml}, \mathrm{pH} 1.2,3.0$ 및 6.0에서 반응시켜 아질산염 분해능을 실험한 결과는 Fig. 3과 같다. Positive control인 Vit. C와 용매 분획별 시료 모두 $\mathrm{pH}$ 가 감소할수록 Vit. C는 $22.5 \%, 50.0 \%$, $85.4 \%$ 로 아질산염 소거능이 증가했으며 4 개의 용매 분획물 역시 $\mathrm{pH}$ 가 낮은 조건에서 아질산염 소거능이 높게 나타났다. $\mathrm{pH} 1.2$ 에서 부탄올 분획층이 $57.8 \%$ 로 아질산염 소거능이 가 장 높았고, $\mathrm{pH} 3.0$ 과 6.0에서도 부탄올 분획층이 다른 분획층 보다 아질산염 소거능이 높았다. 그 다음은 $\mathrm{pH} 1.2$ 에서 메탄올 분획층 $(41.5 \%)$, 핵산 분획층 $(35.7 \%)$, 수층(22.4\%)의 순으로 나 타났다. 이러한 결과는 모자반 분획물은 인체의 위 $\mathrm{pH}$ 조건과

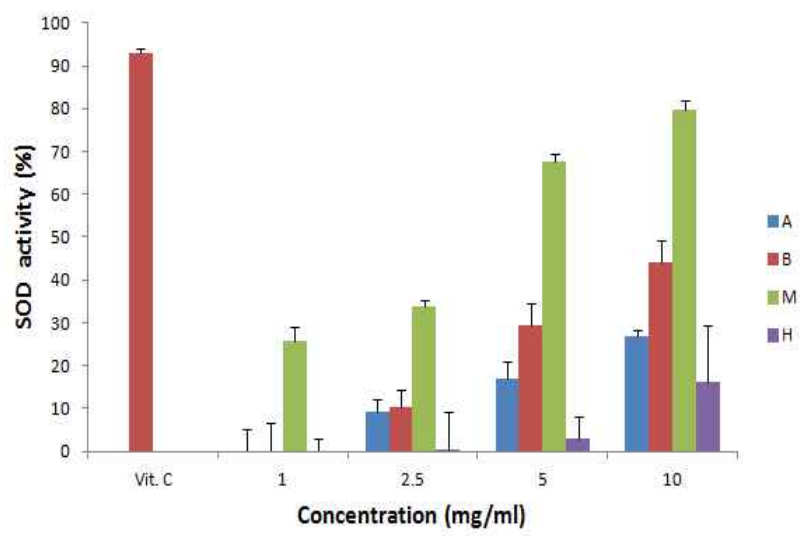

Fig. 2. Superoxide dismutase (SOD) activities of solvent fractions of Sargassum fulvellum Results are mean \pm S.D. of triplicate data. Vit. C $(0.1 \mathrm{mg} / \mathrm{ml}$, ascorbic acid $)$ is used as positive control. A: Aqueous fr., B: Butanol fr., M: Methanol fr., H: Hexane fr.
비슷한 $\mathrm{pH} 1.2$ 에서 활성이 가장 높은 것으로 나타났다. 모든 분획물의 활성은 $\mathrm{pH}$ 가 증가함에 따라 점차 감소하였으며 $\mathrm{pH}$ 6.0에서는 모든 분획물이 $22.1 \%$ 미만으로 낮은 소거능을 나타 내었다. 아질산염 소거능은 산성 영역에서 nitrosamine의 생 성인자인 아질산염을 효과적으로 소거하여 니트로사민의 생 성을 억제하는 것으로 알려져 있다.

Park 등[29]은 모자반 에탄올 추출물의 아질산염 소거효과 는 $\mathrm{pH} 1.2$ 조건에서는 51.5 64.2\%로 나타났으며, $\mathrm{pH}$ 4.2에서 는 26.8 42.6\%, pH 6.0에서는 5.1 11.7\%로 나타나 $\mathrm{pH}$ 가 높아 짐에 따라 아질산염의 효과는 떨어지는 것으로 나타났으며 농도증가에 따른 소거 효과 정도는 현저히 증가하지 않은 것 으로 보고하였다. 물 추출물의 아질산염 소거효과를 측정하였 는데 $\mathrm{pH} 1.2$ 강산성 조건에서는 27.6 $61.8 \%$ 의 소거효과를 나 타냈으며, 시료 농도가 증가함에 따라서 현저하게 소거능이 증가하였다.

Choi 등[8]이 보고한 지충이 추출물의 아질산염 소거 활성 에서는 $\mathrm{pH}$ 2.5, $\mathrm{pH} 4.2, \mathrm{pH}$ 6.0의 조건 하에서 추출물별, 농도 별로 실험을 수행하였다. 그 중 $\mathrm{pH} 2.5$ 의 산성 반응용액에서 는 추출물의 첨가 농도가 증가함에 따라 아질산염 소거작용 도 높았으며 $\mathrm{pH} 2.5$ 의 반응용액에서 $0.1 \mathrm{mg} / \mathrm{ml}$ 의 경우, 물 추출물을 제외한 모든 추출물에서 $68.4 \%$ 이상의 높은 아질산 염 소거작용을 보였으며 methanol 추출물이 $89.4 \%$ 로 가장 높 은 아질산염 소거작용을 나타냈다. 참모자반의 부탄올 분획 층이 Park 등[29]의 연구와 비슷한 소거능을 나타냈으며 지충 이와 비교할 대 다소 아질산염 소거능이 떨어지는 것으로 나 타났다.

아질산염은 식품 중에 존재하는 아민류와 반응하여 발암물 질인 nitrosamine을 생성하는 것으로 밝혀져 있으며, 아질산 염을 일정 농도 이상 섭취하게 되면 헤모글로빈을 메타헤모글

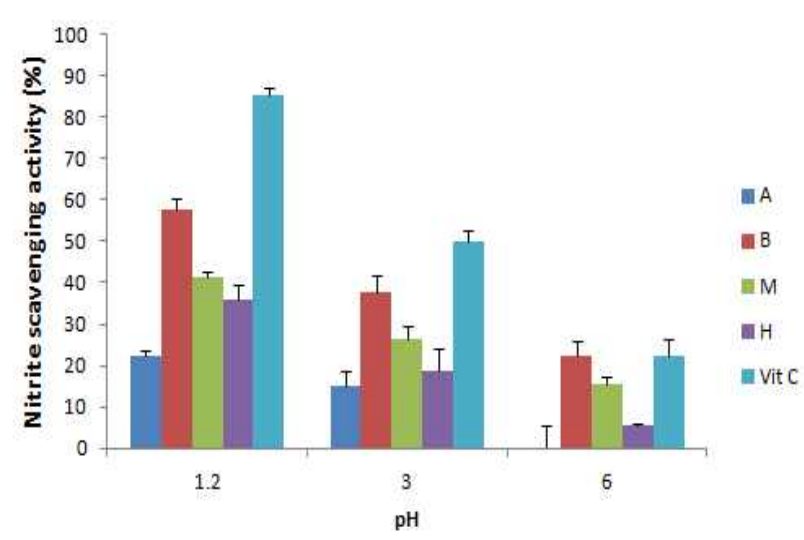

Fig. 3. Nitrite scavenging effects of solvent fractions of Sargassum fulvellum under different $\mathrm{pH}$ conditions. Results are mean \pm S.D. of triplicate data. Vit. C $(0.1$ $\mathrm{mg} / \mathrm{ml}$, ascorbic acid) is used as positive control. A: Aqueous fr., B: Butanol fr., M: Methanol fr., H: Hexane fr. 
로빈으로 전환시키는데, 이 메타헤모글로빈은 각종 중독현상 을 일으키는 것으로 보고되고 있다.

$\mathrm{ADH}$ (alcohol dehydrogenase) 및 ALDH (acetaldehyde dehydrogenase)활성

알코올은 주로 간에서 알코올 탈수소효소(alcohol dehydrogenaase, ADH), cytochrome p450 2E1 (CYP2E1) 및 catalase에 의하여 아세트알데히드로 분해되는데 만성적 알코올 섭 취 시 생성된 과량의 아세트알데히드는 간독성을 촉진시킬 뿐만 아니라 혈압저하와 뇌로의 혈액순환을 악화시켜 두통이 나 메스꺼움, 구토, 현기증, 설사, 근육통 등의 숙취 증상을 야기한다. 체내에 들어온 알코올의 $80 \sim 90 \%$ 는 간세포에 존재 하는 alcohol dehydrogenase (ADH)에 의해 먼저 분해되고, 다시 aldehyde dehydrogenase (ALDH) 효소에 의해 대사되 어 acetic acid를 형성한 후 이산화탄소와 물로 가수분해 된다.

참모자반 분획물의 알코올 분해효소에 대한 $\mathrm{ADH}$ activity 변화를 측정한 결과는 Fig. 4 와 같다. 대조구의 흡광도의 값을 100 으로 하였을 때 이미 숙취 해소 기능이 높은 것으로 알려진 hepos (positive control)는 처방전에 따라 $50 \%$ 로 희석하여 사 용하였을 때 $165.9 \%$ 의 $\mathrm{ADH}$ 활성을 나타내었다. 모든 분획층 에서 농도 의존적으로 활성이 증가하였으며 특히 메탄올 분획 층에서 농도 $5 \mathrm{mg} / \mathrm{ml}$ 인 경우 $120.3 \%, 10 \mathrm{mg} / \mathrm{ml}$ 인 경우 $177.0 \%$ 로 나타났다. $10 \mathrm{mg} / \mathrm{ml}$ 농도에서 부탄올층이 $143.8 \%$, 수층이 $139.8 \%$, 핵산층이 $129.3 \%$ 로 나타났다.

개발된 대부분의 숙취해소 제품은 $\mathrm{ADH}$ 효소 활성을 촉진 시키는 것에 초점이 맞추어져 있으나, 음주 후 실제적으로 느 끼는 숙취증상은 acetaldehyde에 의한 것으로 ALDH 효소 활 성을 촉진시키는 소재 발굴에 관심이 집중되고 있다. 참모자 반 분획물에 대한 $\mathrm{ALDH}$ 활성은 대조구의 흡광도 값을 100 으 로 하였을 때 모자반 분획물의 경우, 농도가 증가함에 따라

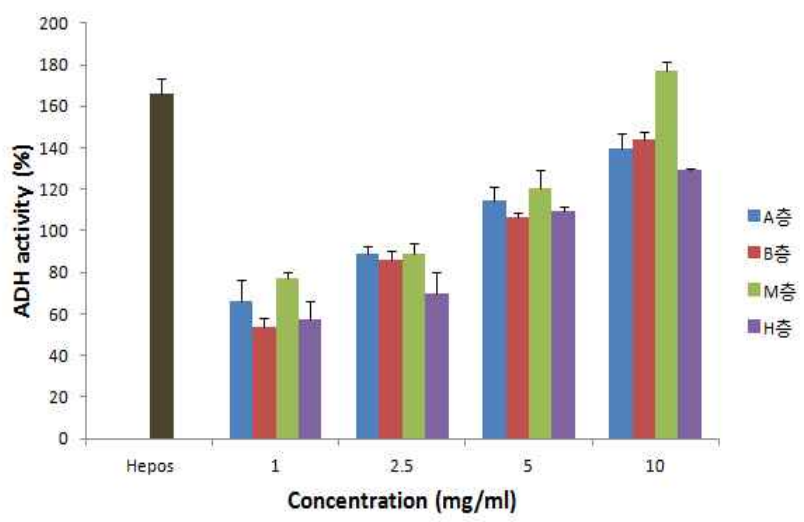

Fig. 4. Alcohol dehydrogenase (ADH) activity of solvent fraction from Sargassum fulvellum Results are mean \pm S.D. of triplicate data. $50 \%$ Hepos is used as positive control. A: Aqueous fr., B: Butanol fr., M: Methanol fr., H: Hexane fr.
$\mathrm{ALDH}$ 활성은 현저히 증가하는 것으로 나타났다(Fig. 5). 참모 자반 추출물 $10 \mathrm{mg} / \mathrm{ml}$ 농도에서 메탄올 분획층의 ALDH 활 성은 $167.4 \%$ 로 positive control (hepos)의 $\mathrm{ALDH}$ 활성 $(161.2 \%)$ 보다 높은 활성을 나타내었다. 이러한 결과는 참모자 반 추출물이 숙취해소를 위한 소재로 개발될 가능성이 매우 높을 것으로 기대된다. 일반적으로 해조류는 숙취해소 식품으 로 많이 섭취되고 있으나 해조류가 숙취해소에 어떤 영향을 미치는가에 대한 연구 결과는 거의 없는 실정이다. Cho 등[6] 의 매생이 추출물과 비교해 볼 때 참모자반에서 높은 알코올 분해 활성을 나타내었다.

\section{a-Glucosidase 활성억제 효과}

a-Glucosidase는 소장 상피세포의 brush-border membrane에 존재하는 효소로서 a-amylase에 의해 분해된 당질을 최종적으로 단당류로 전환시킨다. 이러한 효소의 활성 저해는 당질 가수분해와 흡수과정을 지연시킴으로서 식후 당 농도를 제한한다. 따라서 a-glucosidase 저해제는 소장점막의 미세융 모에 존재하는 이당류의 분해효소를 가역적으로 억제하여 탄 수화물의 흡수를 지연시키는 역할을 하며, 소장 전체에 포도 당이 흡수되어 식후 혈당 상승을 완만하게 한다. 이러한 제 2형 당뇨병은 현재 세계적으로 급격히 증가하고 있는 추세이 며 유전, 생활습관 등 여러 가지 발병 요인 가운데 특히, 식생 활과 관련이 깊은 만성질환이다.

참모자반 분획물로 부터 항당뇨 효과를 분석하기 위하여 a-glucosidase 저해활성을 측정하였다(Fig. 6). 본 연구에서 positive control로 사용한 acarbose는 a-glucosidase 억제제로 서 농도 $0.5 \mathrm{mg} / \mathrm{ml}$ 에서 $40.4 \%$ 의 억제효과를 보였으며 4 개의 용매 분획물 중 핵산 분획층에서 a-glucosidase 활성이 농도 의존적으로 현저하게 감소하는 것으로 나타났으며, 핵산층 2 $\mathrm{mg} / \mathrm{ml}$ 농도에서 $94.1 \%$ 의 항당뇨 효과를 나타내었다. 그런데



Fig. 5. Aldehyde dehydrogenase (ALDH) activity of solvent fraction from Sargassum fulvellum Results are mean \pm S.D. of triplicate data. $50 \%$ Hepos is used as positive control. A: Aqueous fr., B: Butanol fr., M: Methanol fr., $\mathrm{H}$ : Hexane fr. 


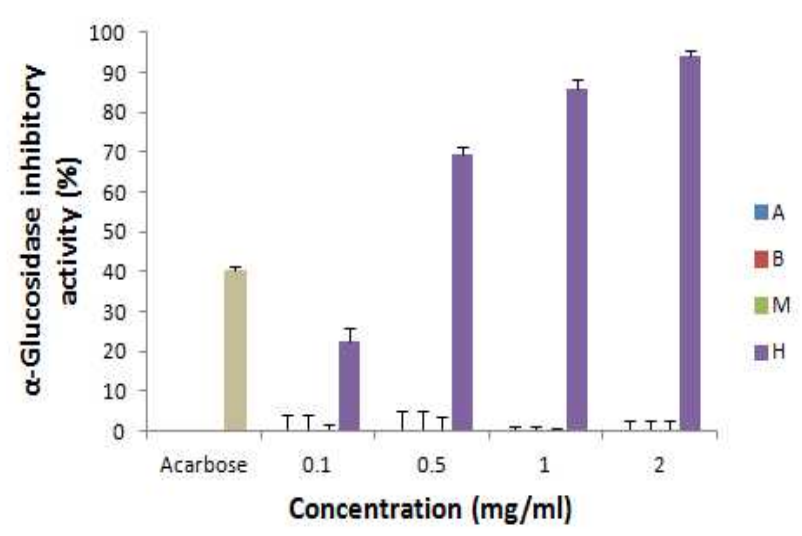

Fig. 6. Inhibitory effects of solvent fractions from Sargassum fulvellum on a-glucosidase. Results are mean \pm S.D. of triplicate data. Acarbose $(0.5 \mathrm{mg} / \mathrm{ml})$ is used as positive control. A: Aqueous fr., B: Butanol fr., M: Methanol fr., $\mathrm{H}$ : Hexane fr.

부탄올층, 메탄올층, 수층은 항당뇨 활성이 거의 없는 것으로 나타났다.

Lee 등[24]은 Sargassum family (S. thunbergii, S. horneri, S. confusum, $S$. yezoense, $S$. miyabei) 5종에 대해 a-glucosidase 억제활성을 측정한 결과 $S$. yezoenseㅏㅏ 가장 우수한 효과를 나 타냈다고 보고하였다. 농도 $0.1 \mathrm{mg} / \mathrm{ml}$ 에서 $S$. yezoense는 $84.5 \%$, S. miyabei는 $84.1 \%$, S. confusum는 $75.9 \%$, S. horneri와 S. thunbergii는 5\% 미만의 a-glucosidase 저해효과를 나타냈 다. Lee 등[24]은 a-glucosidase억제 활성을 나타내는 물질이 sargaquinoic acid와 sargahydroquinolic acid인 것으로 구조 동정 하였다. 이러한 결과는 모자반은 종에 따라 $a$ -glucosidase 억제효과가 큰 차이를 보였으며, 특히 본 실험에 사용된 참모자반은 핵산 분획층에서 항당뇨 활성이 높은 것으 로 나타나 모자반이 훌륭한 항당뇨 소재로 개발 될 가능성이 높을 것으로 기대된다.

\section{Elastase 저해활성}

피부의 조직 진피 속에는 collagen과 피부의 탄력성에 관련 된 elastin 이 그물망 구조를 형성하고 있는데 elastin이 elastase에 의하여 분해되면 피부가 처지고 주름이 생겨서 내인성 피부 노화가 발생한다[21]. 주름생성의 주원인 효소로 알려져 있는 elastase는 체내의 elastin을 분해하는 백혈구 과립 효소 중의 하나로 이상조직에서는 활성이 높아져 조직파괴의 직접 적인 원인이 되어 피부의 주름 및 탄력성 소실 등을 유발한다. 이러한 elastase 활성을 저해시켜 주름생성을 억제시킴으로 피 부 노화를 방지하려는 연구가 활발히 진행되어 많은 elastase 저해제들이 보고되어 있다[21].

본 연구에서 모자반의 메탄올 추출 분획층의 elastase 저해 활성을 조사한 결과는 Fig. 7 과 같다. 활성이 나타난 3 개의 분 획층은 농도 의존적으로 저해효과가 증가하였으며 추출물 농

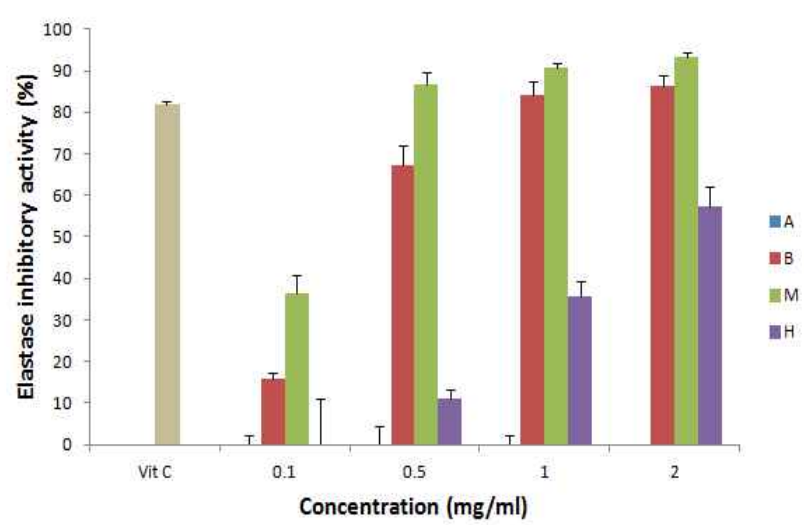

Fig. 7. Elastase inhibitory effects of solvent fractions from Sargassum fulvellum Results are mean \pm S.D. of triplicate data. Vit. C $(1 \mathrm{mg} / \mathrm{ml})$ is used as positive control. A: Aqueous fr., B: Butanol fr., M: Methanol fr., H: Hexane fr.

도 $2 \mathrm{mg} / \mathrm{ml}$ 에서 메탄올 분획층은 $93.2 \%$, 부탄올 분획층은 $86.4 \%$ 로서 positive control로 사용한 Vit. C $(1 \mathrm{mg} / \mathrm{ml})$ 보다 훨씬 높은 elastase 저해활성을 나타내었다. 핵산 분획층은 낮 은 농도 $(0.1 \mathrm{mg} / \mathrm{ml})$ 에서는 활성을 보이지 않다가 농도가 점점 증가할수록 농도 의존적으로 증가하여 $2 \mathrm{mg} / \mathrm{m}$ 에서 $57.4 \%$ 의 저해활성을 나타냈으며 수층에서는 저해활성이 검출되지 않 았다.

특히 메탄올 분획층과 부탄올 분획층에서 대조군보다 뛰어 난 elastase 저해 효과를 가지고 있는 것으로 나타났으며, 이러 한 결과는 모자반 분획층에 피부의 주름을 개선하는 효과가 있는 생리활성 물질이 있는 것으로 사료된다. 해조류 중에서 elastase 활성에 대항 연구는 $\mathrm{Bu}$ 등[4]이 감태에서 분리한 die$\mathrm{ckol}$ 에서 $\mathrm{IC}_{50} 14.7 \mu \mathrm{g} / \mathrm{ml}$ 로 천연주름 억제제로서 사용가능성 을 확인하였다.

\section{References}

1. Ahn, S. M., Hong, Y. K., Kwon, G. S. and Shon, H. Y. 2011. Evaluation of antioxidant and nitrite scavenging activity of seaweed extracts. J. Life Sci. 21, 576-583.

2. Bae, S. J. 2004. Anticarcinogenic effect of Sargassum fulvellum fractions on sever hum cancer cell lines in vito. J. Korean Soc. Food Sci. Nutr. 33, 480-486.

3. Blois, M. S. 1958. Antioxidant determination by the use of a stable free radical. Nature 26, 1198-1200.

4. Bu, H.-J., Ham, M. H., Kim, J. M., Lee, S.-J., Hyun, J. W. and Lee, N. H. 2006. Elastase and hyaluronidase inhibition activities of phlorotannins isolated from Ecklonia cava. Korean J. Phamacogn. 37, 92-96.

5. Cho, S.-H., Kang, S.-E., Cho, J.-Y., Kim, A.-R., Park, S.-M., Hong, Y.-K. and Ahn, D.-H. 2007. The antioxidant properties of brown seaweed (Sargassum siliquastrum) extracts. J. Med Food 10, 479-485. 
6. Cho, E. K., Yoo, S. K. and Choi, Y. J. 2011. Inhibitory effects of Maesaengi (Capsosiphon fulvescens) extracts on angiotensin converting enzyme and a-glucosidase. J. Life Sci. 21, 811-818.

7. Choi, J. T., Joo. H. K. and Lee. S. K. 1995. The effect of schizandrae fruits extract on alcohol fermentation and enzyme activities of Saccharomyces cervisiae. Agric. Chem Biotechnol. 38, 278-282.

8. Choi, S. Y., Kim, S. Y., Hur, J. M., Choi, H. G. and Sung, N. J. 2006. Antioxidant activity of solvent extracts from Sargassum thunbergii. J. Korean Soc. Food Sci. Nutr. 35, 139-144.

9. Gray, J. I and Dugan, Jr L. R. 1975. Inhibition of $\mathrm{N}$-nitrosamine formation in model food systems. J. Food Sci. 40, 981-984.

10. Haung, H. L. and Wang, B. G. 2004. Antioxidant capacity and lipophilic content of seaweeds collected from Qingdao coastline. J. Agric. Food Chem 52, 4993-4997.

11. Heo, S.-J., Park, E.-J., Lee, K.-W. and Jeon, Y.-J. 2005. Antioxidant activities of enzymatic extracts from brown seaweeds. Bioresources Technol. 96, 1613-1623.

12. Heo, S. J. and Jeon, Y. J. 2005. Antioxidant effect and protecting effect against cell damage by enzymatic hydrolysates from marine algae. Food Industry Nutr. 10, 31-41.

13. Hwang, P.-A., Chien, S.-Y., Chan, Y.-L., Lu, M. K., Wu, C.-H., Kong, Z.-L. and $\mathrm{Wu}$, C.-J. 2001. Inhibition of lipopolysaccharide (LPS)-induced inflammatory responses by Sargassum hemiphyllum sulfated polysaccharide extract in RAW 264.7 macrophage cells. J. Agric. Food Chem 59, 2062-2068.

14. James, A. E. K., Timothy, D. W. and Gorden, L. 1996. Inhibition of human leukocyte and porcine pancreatic elastase by homologues of bovine pancreatic tyrosinase inhibitors. Biochem 35, 9090-9096.

15. Kim, J. Y., Lee, J. A., Kim, K. N., Yoon, W. J., Lee W. J. and Park, S. Y. 2007. Antioxidative and antimicrobial activities of Sargassum muticum Extracts. J. Korean Soc. Food Sci. Nutr. 36, 663-669.

16. Kim, M. H., Chung, Y. T., Lee, J. H., Park, Y. S., Shin, M. K., Kim, H. S., Kim, D. H. and Lee, H. Y. 2000. Hepatic detoxification activity and reduction of serum alcohol concentration of Hovenia dulicis $\mathrm{T}_{\mathrm{HUNB}}$ from Korea and China. Korean J. Medicinal Crop Sci. 8, 225-233.

17. Kim, S. H., Choi, D. S., Athukorala, Y., Jeon, Y. J., Senevirathne, M. and Rha, C. K. 2007. Antioxidant activity of sulfated polysaccharides isolated from Sargassum fulvellum J. Food Sci. Nutr. 12, 65-73.

18. Kim, S. N. and Choi, H. Y., Lee, W., Park, G. M., Shin, W. S. and Kim, Y. K. 2008. Sargaquinolic acid and sargahydroquinolic acid from Sargassum yezoense stimulate adipocyte differentiation through PPARalpha/gamma activation in 3T3-L1 cells. FEBS Lett. 582, 3465-3472.

19. Kong, C. S., Um, Y. R., Lee, J. I., Kim, Y. A., Lee, J. S. and Seo, Y. W. 2008. Inhibition effects of extracts and its solvent fractions isolated from Limanium tetragonum on growth of human cancer cells. Korean J. Biotechnol. Bioeng. 23, 177-182.
20. Koo, J. G., Choi, Y. S. and Kwak, J. K. 2001. Blood-anticoagulant activity of fucoidans from sporophylls of Undaria pinnatifia, Laminaria religiosa, Hizikia fusiforme and Sargassum fulvellum in Korea. J. Korean Fish Soc. 34, 515-520.

21. Kwak, S. C., Kim, S. A. and Lee, M. S. 2005. The correlation of antioxidative effects of 5 Korean common edible seaweeds and total polyphenol content. J. Korean Soc. Food Sci. Nutr. 34, 1143-1150.

22. Kwak. Y. J., Lee. D. H., Kim. N. M. and Lee. J. S. 2005. Screening and extraction condition of anti-skin aging elastase inhibitor from medical plants. Korean J. Medicinal Crop Sci. 13, 213-216.

23. Lee, B. H., Choi, B. W., Chun, J. H. and Yu, B. S. 1996. Extraction of water soluble antioxidants from seaweeds. J. Korean Ind Eng. Chem 7, 1069-1077.

24. Lee, D. W., Ko, J. G., Ko, H. R., Park, S. J., Ryu, H. J., Kim, H. C., Cho, J. W., Ha, J. H. and Ko, S. B. 2011. Development of olle tea using Jeju fucoidan. The Korea academia-industrial cooperation society.

25. Lee, E. H., Han, J., Ahn, H. R., Kim, M. C., Kim, C. Y., Pan, C. H., Um, B. H. and Jung, S. H. 2009. Inhibitory effects of the compounds isolated from Sargassum yezoense on a -glucosidase and oxidative stress. Korean J. Pharmacogn. 40, 150-154.

26. Lee, K.-S., Kim, G.-H., Seong, B.-J., Kim, H.-H., Kim, M.-Y. and Kim, M. R. 2009. Effects of aqueous medicinal herb extracts and aqueous fermented extracts on alcoholmetabolizing enzyme activities. Korean J. Food Preserv. 16, 259-265.

27. Lee, S. O., Lee, H. J., Yu, M. H., Im, H. G. and Lee, I. S. 2005. Total polyphenol contents and antioxidant activities of methanol extracts from vegetables produced in Ulung Island. Korean J. Food Sci. Technol. 37, 233-243.

28. Lim, S. M., Cheung, P. C. K. and Ooi, V. E. C. 2002. Evaluation of antioxidative activity of extracts from a brown seaweed, Sargassum siliquastrum J. Agirc. Food Chem 50, 3862-3866.

29. Matsukawa, R., Dubinsky, Z., Kishimoto, E., Masaki, K., Masuda, Y. and Takeuchi, T. 1997. A comparison of screening methods for antioxidant activity in seaweeds. $J$. Appl. Phycol. 9, 29-35

30. Oh, J. K., Shin, Y. O., Shon, H. S. and Seo, R. M. 2003. Effect of functional food including seaweeds extracts supplementation on hematological variables and antioxidant system. Korean J. Physic. Edu. 42, 895-903.

31. Park, J. W., Lee, J. H., Yoon, M. and Kim, C. H. 2001. Nitrite scavenging activity of the ethanol and water extracts obtained from Hizikia fusiforme and Sargassum fulvellum Korean J. Life Sci. 11, 321-327.

32. Tibbot, B. K. and Skadsen, R. W. 1996. Molecular cloning and characterization of a gibberellin-inducible, putative a -glucosidase gene from berley. Plant Mol. Biol. 30, 229-241.

33. Tottmar, S. O., Petterson, H. K. and Kiessling, H. 1973. The subcellular distribution and properties of aldehyde dehydrogenase in rat liver. Biochem J. 135, 577-581.

34. Yoon, S. Y., Lee, S. Y., Kim, K. B. W. R., Song, E. J., Lee, 
S J., Lee, C. J., Park, N. B., Jung, J. Y., Kwak, J. H., Nam, K. W. and Ahn, D. H. 2010. Antimicrobial activity of the Sargassum fulvellum ethanol extract and the effect of temperature and $\mathrm{pH}$ on their activity. Korean J. Food Sci. Technol. 42, 155-159.

초록 : 참모자반 메탄올 추출 분획물의 항산화 및 숙취해소능과 a-glucosidase 활성저해효과

강수희 $^{\dagger} \cdot$ 조은경 ${ }^{\dagger} \cdot$ 최영주 ${ }^{*}$

(신라대학교 의생명과학대학 식품영양학과)

참모자반 분획물은 극성에 따라 핵산, 메탄올, 부탄올 및 수층 순으로 분획하여 4 개의 분획층을 얻었으며, 각 분획층의 생리활성을 요약하면 다음과 같다. 항산화 활성은 DPPH radical 소거능과 SOD 활성을 측정한 결과 모두 농도 의존적으로 증가하였으며 특히 메탄올 분획 층에서 가장 높은 항산화 효과를 보였다. 아질산염 소거능 실험에서는 부탄올 층이 $\mathrm{pH} 1.2$ 에서 $57.8 \%$ 로 4 개의 분획물중 가장 높은 아질산염 소거능을 나타냈다. 숙취 해소 능을 측정하기 위하여 $\mathrm{ADH}$ 활성과 $\mathrm{ALDH}$ 활성을 측정하였다. 대조구로 사용한 흡광도 값을 100 으로 하였을 때 positive control로 사용한 hepos가 150 167\% 의 활성을 나타내었으며 4가지 분획층 모두 농도 의존적으로 활 성이 증가하였다. 특히 ALDH에서는 메탄올 분획층이 $10 \mathrm{mg} / \mathrm{ml}$ 농도에서 $167.4 \%$ 의 활성을 나타내어 hepos와 비슷한 효과를 보였다. 참모자반 분획물의 혈당강하 효과는 a-glucosidase 활성억제 효과로 측정하였다. a -glucosidase 활성억제 효과는 핵산 분획층에서 $2 \mathrm{mg} / \mathrm{ml}$ 의 농도에서 $94.1 \%$ 로 아주 높은 항당뇨 효과를 나타내었 다. 그런데 부탄올층, 메탄올층 및 수층은 혈당강하효과가 거의 없는 것으로 나타났다. 피부주름예방을 측정하기 위하여 수행한 elastase 저해효과 실험에서 메탄올 분획층에서 농도 의존적으로 높은 주름개선효과가 나타났으며 $2 \mathrm{mg} / \mathrm{ml}$ 농도에서 $93.2 \%$ 의 효과를 나타냈으며, positive control로 사용한 Vit. C $(1 \mathrm{mg} / \mathrm{ml})$ 보다 더 높은 활성을 나타냈다. 이러한 결과는 모자반 메탄올 추출물 중 특히 메탄올 분획층이 탁월한 주름개선 효과, 숙취 해소능과 항산화 효과가 있는 것으로 사료되며, 핵산층은 혈당강하 효과가 높은 것으로 나타났다. 따라서 모자반 유기용매 분획물은 천연 기능성소재로서의 사용 가능성이 매우 높을 것으로 사료된다. 